\title{
Analyzing Indicators of the Results of Applying Forecasting Methods for Production Plans: A Case Study at the Diyala State Company for Electrical Industries
}

\author{
Emad Khaleel Ismael \\ Faculty of Business Administration, \\ Al-Mamoun University College, \\ 14 Ramadan St, Baghdad, Iraq
}

DOI: https://doi.org/10.36941/mjss-2021-0044

\begin{abstract}
Economic organizations operate in a dynamic environment, which necessitates the use of quantitative techniques to make their decisions. Here, the role of forecasting production plans emerges. So, this study aims to analysis of the results of applying forecasting methods to production plans for the past years, in the Diyala State Company for Electrical Industries. The Diyala State Company for Electrical Industries was chosen as a field of research for its role in providing distinguished products as well as the development and growth of its products and quality, and because it produces many products, and the study period was limited to ten years, from 2010 to 2019. This study used the descriptive approach in the theoretical side of the study, on the practical side, the current study used the statistical application (SPSS), and some other statistical means to process and analyze what was collected from data related to the company, the research sample, from its official website. The research concluded that flooding the Iraqi market with alternative imported products for the products of the Electrical Industries Company led to the cessation of production of some of the company's products, as a result, its resources were not invested efficiently and production costs were high. The current study suggested to the Ministry of Electricity to buy the company's products, as these products have a good quality comparing with the foreign ones.
\end{abstract}

Keywords: Forecasting methods, Planning, Production plans, Actual production, Pointers

\section{Introduction}

The task of analyzing indicators of applying the results of forecasting methods for production plans is one of the basic tasks of higher management.

As through it, production requirements are determined for a specific future period, and this requires concerted efforts of all workers in the organization in order to succeed in this task, and reach a competitive advantage that contributes to developing the market value of the institution.

As the industrial companies have become operating in an open environment that witnesses intense competition, especially recently after many companies entered the competition line, and all of them set their primary goal is to reach customer satisfaction and achieve satisfaction.

So, this research is concerned with theoretical (knowledge) and applied data for the indicators of the results of methods of forecasting production plans and examining the actual reality of 
production and the recommendations necessary to improve future production plans.

\section{Research Methodology}

\subsection{Research Problem}

Economic organizations operate in a dynamic environment, which necessitates the use of quantitative techniques to make their decisions. Here, the role of forecasting production plans emerges. So, this study discusses the analysis of the results of applying forecasting methods to production plans for the past years, in the Diyala State Company for Electrical Industries. where it seems that the reality of the industries in Iraq in general, and the electrical industries company in particular, need such indicators, for the purpose of guiding them in the near and medium future, Especially after the entry of a number of foreign and local industrial companies to compete in the Iraqi market and provide the same products, and each sought to predict the future reality of the market in order to meet its needs.

Accordingly, the research problem is centered by raising the following question:

- What is the nature of the results of the analysis of the indicators of methods for forecasting production plans with a view to improving them in the researched company?

\subsection{Research Aims}

The research seeks to achieve the following Aims:

- Introduce forecasting and its methods, as well as its importance in production plans.

- Analyzing indicators of the results of applying forecasting methods for production plans in the Diyala State Company for Electrical Industries

- Provide some recommendations about future of production in the Diyala State Company for Electrical Industries, based on the results of the research.

\subsection{Research Important}

Forecasting is one of the important processes and activities in production management, through which the volume of demand can be anticipated by consumers and adapted to the expected quantity of production for the purpose of balancing between them, so the importance of this study lies in two aspects, the first is theoretical through discussing the literature of the study regarding the concept of forecasting and its methods, as well as On its importance in production plans, On the other hand, the study discusses the results of applying forecasting methods to the production plans of the past years for the Diyala State Company for Electrical Industries, in order to find out the positive and negative aspects therein, and thus provide the necessary recommendations in order to address some of the defects in those methods.

\subsection{Spatial and temporal limits of the research}

Diyala State Company for Electrical Industries was chosen as a field of research for its role in providing distinguished products as well as the development and growth of its products and quality, and because it produces many products, and the study period was limited to ten years, from 2010 to 2019.

\subsection{Data collection methods}

In order to obtain the required data for the purposes of study and analysis and to extract the required results in implementing the research objectives, the following methods have been followed: 
1) Collect data directly from the company's business plan documents, which were prepared by the relevant committee in the Diyala State Company.

2) Entering the company's website through the internet to provide other information necessary to complete the research requirements.

\section{Theoretical Framework}

\subsection{Definition of Forecasting}

"Forecasting is estimates of future uncertain events occurring or their timing or magnitude" (Kumar \& Suresh, 200o), and "Buzarth et al." Defined prediction as "timing of the future level of some common variables which include levels of demand, levels of supply, prices" (Bozarth \& Handfield 2008,266) Often, forecasting is the first step for determining the required future energy, required work plans and short-term operations, for example when trying to make a decision regarding determining the physical size of a new hospital and the number of doctors and nurses required for that as well as the required medical equipment and equipment, this can only be done After determining the number of patients they are expected to arrive at the hospital to be established. The prediction was defined as "an attempt to estimate the market need of a particular good or service or a mix of commodities during a certain future period" and was also defined as "the art and science of anticipating events in the future"( Avci, 2019,5).

\subsection{The importance offorecasting to production plans}

Predictions are very necessary for the operations of commercial enterprises for the purpose of operating smoothly, (Ali, 2017,4). as they provide information that can assist managers in directing future activities towards organizational goals, and production managers are concerned with forecasts that are made by (or in conjunction) with marketing However, 2managers also use expectations to estimate raw material prices, to plan appropriate levels of employees, and to determine stock quantities to be held and a wide range of other activities. This results in better energy use, more responsive customer service, and improved profitability. (Nowicka,2016,29).

On the other hand, the general administrative costs increase by $1 \%$ for each inaccuracy by $1 \%$ in the company's sales volume forecast for example, a projected error of $10 \%$ (either positive or negative) for a product in a region increases the overall administrative costs for that product in that region by 10\% (Chapman, 2013, 46).

Prediction is very important and necessary for any plant through the use of prediction methods to determine the demand in the future, and this is possible in the case of providing more information for the previous request by identifying the influencing factors and measuring their impact. If, in the past, demand can be explained by a set of effects on variables, there is a high probability that future demand is predictable (Poiger,2010,42).

\subsection{Forecasting Methods}

There are many methods for forecasting, as appropriate methods are chosen based on the decision maker's need and can be classified in two ways, as follows:

1) Qualitative methods.

2) Quantitative methods

Managers often use qualitative methods based on opinions, past experiences and even best guesses (Russell \& Taylor, 2011,501).

For quantitative methods, time series models assume that all information needed to formulate the prediction model is in the time series of the data. A time series is a series of observations obtained during regular time periods (Sanders, 2015,270). Also, managers use dual methods of both types 
(quantity and quality). In other words, quantitative methods are used for the purpose of assigning qualitative methods in making decisions, In a comparative study of long-term market prediction methods,( Armstrong and Grohman) concluded that econometric methods provide far more accurate long-term forecasts than expert opinion or time series analysis (Armstrong \& Green, 2017,7) .

The quantitative methods for prediction purposes are as follows:

1. Simple Moving Average Method

In the case that the prediction of the moving average for four periods is done according to the following formula: $F_{t}=$ At $-1+$ At-2 + At-3 + At- $4 / 4 ; F_{t}=$ Forecasting for the period $t ; A_{t}=$ Actual sold units for the period $t ; n=$ number of periods or data points used in the moving average.

2. Exponential Smoothing Method Simple

Simple exponential demobilization method is a type of moving average. It is widely used in forecasting demand for products and storage and is applied with high efficiency using the computer because of the lack of data for past periods required by this method.

The general rule for this method is written according to the following formula: $\mathrm{Ft}=\mathrm{A}_{\mathrm{t}-1}+\alpha$ $\left(A_{t-1}-F_{t-1}\right) ; F t=$ prediction for the period $t ; F_{t-1}=$ prediction for the past period; $A_{t-1}=$ real time order; $\alpha=$ exponential discharge constant

3. Trend line Method

This method assumes that the demand for products changes in excess or decrease over time and that what happened to demand in the past can be repeated in the future. This method is a common method used in demand forecasts and the formula used for the trend line equation is written as follows: $\mathrm{Y}=\mathrm{a}+\mathrm{b} \mathrm{X}$; As: $\mathrm{Y}=$ Prediction of the request; $\mathrm{X}=$ time period; $\mathrm{a}=$ constant; $\mathrm{b}=$ equation curve or degree of slope of the equation.

\section{Practical Side}

\subsection{Company profile}

Diyala State Company is one of the companies of the Ministry of Industry and Minerals, established since 1974 in the name of the industrial complex, which consists of laboratories (ceiling fans, steam irons, spark plugs and electrical scales) and began experimental operation in 1978 and in 1983 the factories of electrical transformers (distribution and capacity) were opened and from Then Alarcon lab in 1990 and optical cable in 2003.

In 2016, Diyala State Company for Electrical Industries was merged with Al-Mansour State Company under the name (General Diyala Company) and Al- Mansour Factory Company was unlinked from our company's factories on 12/1/2017 and among the most important products of the company:

1. Distribution transformers.

2. Power transformers

3. Electrical and electronic scales

4. Optical cable.

5. Ceiling fans.

6. Steam iron.

7. spark plugs.

8. Gas (argon and oxygen).

It is worth noting that each of the factories (ceiling fans, steam irons, mug candles) are currently suspended due to the old design, machinery, and economic ineffectiveness of their production. Also, the Alarcon plant for the production of oxygen and argon is stopped due to the instability of electricity. To support and assign the producing laboratories. According to the above, the research will be limited to two products:

1. Distribution transformers. 
2. Electrical scales.

This is due to stopping the production of other products on the one hand and the lack of necessary data for the purposes of completing the research.

Table No. (1) represents The data obtained from the Electrical Industries Company for ten years are as follows:

Table 1: Represents the data obtained from the Electrical Industries Company for ten years

\begin{tabular}{|c|c|c|c|c|c|c|}
\hline \multicolumn{2}{|c|}{ (Electrical scales) } & \multicolumn{3}{c|}{ (Distribution Transformers) } \\
\hline Quantities of production sold & years & sequence & Quantities of production sold & years & sequence \\
\hline 42582 & 2010 & 1. & 2978 & 2010 & 1. & 2. \\
\hline 103522 & 2011 & 2. & 5185 & 2011 & 3. & 4. \\
\hline 105238 & 2012 & 3. & 5392 & 2012 & 5. & 6. \\
\hline 221798 & 2013 & 4. & 6258 & 2013 & 7. & 8. \\
\hline 137450 & 2014 & 5. & 3404 & 2014 & 9. & 10. \\
\hline 88872 & 2015 & 6. & 4928 & 2015 & 11. & 12. \\
\hline 43265 & 2016 & 7. & 622 & 2016 & 13. & 14. \\
\hline 46515 & 2017 & 8. & 1549 & 2017 & 15. & 16. \\
\hline 106697 & 2018 & 9. & 4346 & 2018 & 17. & 18. \\
\hline 56894 & 2019 & 10. & 5231 & 2019 & 19. & 20. \\
\hline
\end{tabular}

4.2 Analysis of forecast indicators for production plans for the product (Distribution Transformers) for the year 2020

\subsubsection{Using the four-period moving average method as follows}

Table No. (2) shows the results of the Forecasting for the year 2020 using the four-period moving average method.

Table 2: Results of the Forecasting for the year 2020 using the four-period moving average method

\begin{tabular}{|c|c|c|}
\hline Forecasting the quantity sold OF (Distribution transformers) For the year 2020 & quantity sold & years \\
\hline $\mathrm{Ft}=\mathrm{A}_{\mathrm{t}-1}+\mathrm{A}_{\mathrm{t}-2}+\mathrm{A}_{\mathrm{t}-3}+\mathrm{A}_{\mathrm{t}-4} / 4$ & 622 & 2016 \\
\hline $\mathrm{F}_{2020}=5231+4346+1549+622 / 4$ & 1549 & 2017 \\
\hline $\mathrm{F}_{2020}=11748 / 4$ & 4346 & 2018 \\
\hline $\mathrm{F}_{2020}=63342.75 \approx 63343$ units & 5231 & 2019 \\
\hline 2937 & -------- & 2020 \\
\hline
\end{tabular}

Source: Author

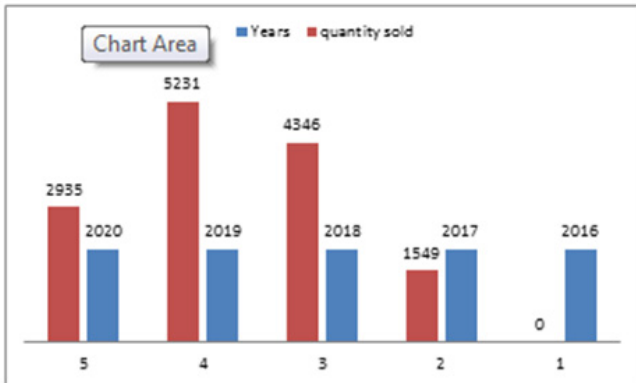

Figure 1: Represent Forecasting for the year 2020 using the four-period moving average method (Distribution Transformers)

Source: Author 


\subsubsection{Using the simple exponential smoothing method, as follows}

Table 3: Shows the results of the Forecasting for the year 2020 using simple exponential Smoothing method (Assuming $\alpha=0.20$ and forecast for the year $2019=2861$ )

\begin{tabular}{|l|c|c|}
\hline Forecasting the quantity sold OF (Distribution transformers) For the year 2020 & quantity sold & years \\
\hline $\mathrm{F}_{\mathrm{t}}=\mathrm{F}_{\mathrm{t}-1}+\alpha\left(\mathrm{A}_{\mathrm{t}-1}-\mathrm{F}_{\mathrm{t}-1}\right)$ & 622 & 2016 \\
\hline $\mathrm{F}_{2020}=\mathbf{2 8 6 1 + 0 . 2 0}(5231-2861)=\mathbf{2 9 3 5}$ & $\mathbf{1 5 4 9}$ & 2017 \\
\hline & 4346 & 2018 \\
\hline & 5231 & 2019 \\
\hline $\mathrm{F}_{2020}=2935$ & ------- & 2020 \\
\hline
\end{tabular}

Source: Author

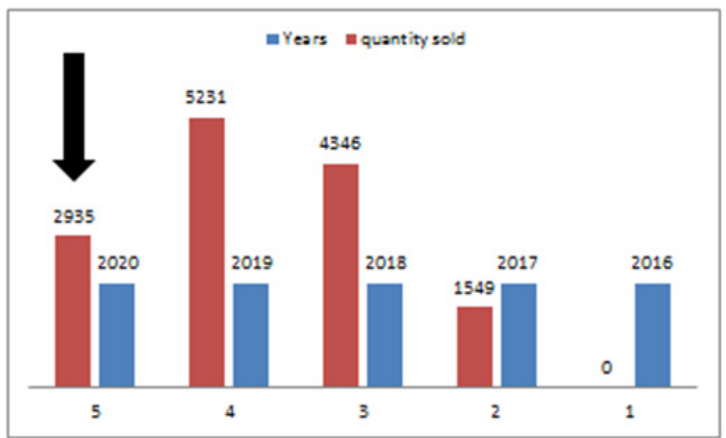

Figure 2: Shows results of the Forecasting for the year 2020 using the simple exponential Smoothing method (Distribution Transformers).

\subsubsection{Using Trend Line Method as Follows}

Table 4: Shows the Forecasting result for the year 2020 using Trend line Method

\begin{tabular}{|c|c|c|c|c|c|}
\hline$(6)$ & $(5)$ & $(4)$ & $(3)$ & $(2)$ & $(1)$ \\
\hline$X^{2}$ & $X Y$ & Y Sold Units & $X$ & YEAR NO. & years \\
\hline 25 & -14890 & 2978 & -5 & 1 & 2010 \\
\hline 16 & -20740 & 5185 & -4 & 2 & 2011 \\
\hline 9 & -16176 & 5392 & -3 & -2 & 2012 \\
\hline 4 & -12516 & 6258 & -1 & 5 & 2013 \\
\hline 1 & -3404 & 3404 & 1 & 6 & 2014 \\
\hline 1 & 4928 & 4928 & 2 & 7 & 2015 \\
\hline 4 & 1244 & 622 & 3 & 8 & 2016 \\
\hline 9 & 4647 & 1549 & 4 & 9 & 2017 \\
\hline 16 & 17384 & 4346 & 5 & 10 & 2018 \\
\hline 25 & 26155 & $\sum \mathrm{Y}=39893$ & $\sum \mathrm{X}=\mathrm{ZERO}$ & 11 & 2019 \\
\hline$\sum \mathrm{X}^{2}=110$ & $\sum \mathrm{XY}=(13368)$ & & & & 20 \\
\hline
\end{tabular}

$\mathrm{Y}=\mathrm{a}+\mathrm{b} \mathrm{X}=3989+(-123.53 \times 6)=3247.82$;

$\mathrm{a}=\sum \mathrm{Y} / \mathrm{n}=39893 / 10=3989$;

$\mathrm{b}=\sum \mathrm{XY} / \sum \mathrm{X}_{2}=-13368 / 110=-123.53$

Source: Author

So: Forecasting the quantity sold OF (Distribution transformers) For the year $2020=3247.82 \approx 3248$ 
(Distribution transformers).

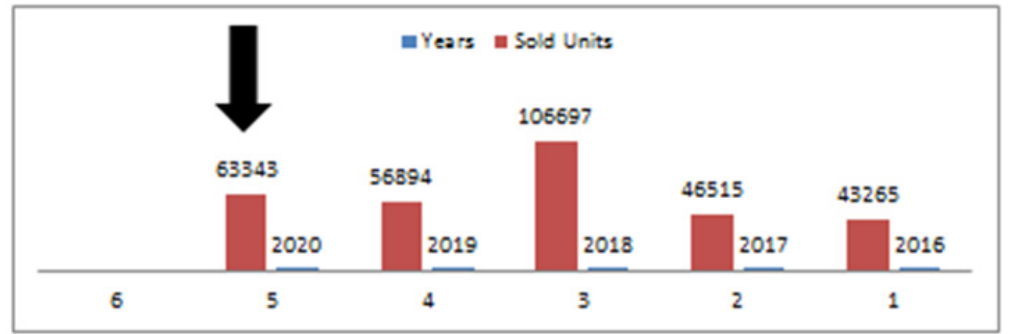

Figure 3: Show results of the Forecasting for the year 2020 using Trend Line Method

\subsubsection{Using the four-period moving average method as follows}

Table 5: Shows the results of the Forecasting for the year 2020 using the four-period moving average method

\begin{tabular}{|c|c|c|}
\hline Forecasting the quantity sold OF (Electrical scales) For the year 2020 & quantity sold & years \\
\hline $\mathrm{Ft}=\mathrm{A}_{\mathrm{t}-\mathrm{1}}+\mathrm{A}_{\mathrm{t}-2}+\mathrm{A}_{\mathrm{t}-3}+\mathrm{A}_{\mathrm{t}-4} / 4$ & 43265 & 2016 \\
\hline $\mathrm{F}_{2020}=56894+106697+46515+43265 / 4$ & 46515 & 2017 \\
\hline $\mathrm{F}_{2020}=253371 / 4$ & 106697 & 2018 \\
\hline $\mathrm{F}_{2020}=63342.75 \approx 63343$ units & 56894 & 2019 \\
\hline 63343 & --------- & 2020 \\
\hline
\end{tabular}

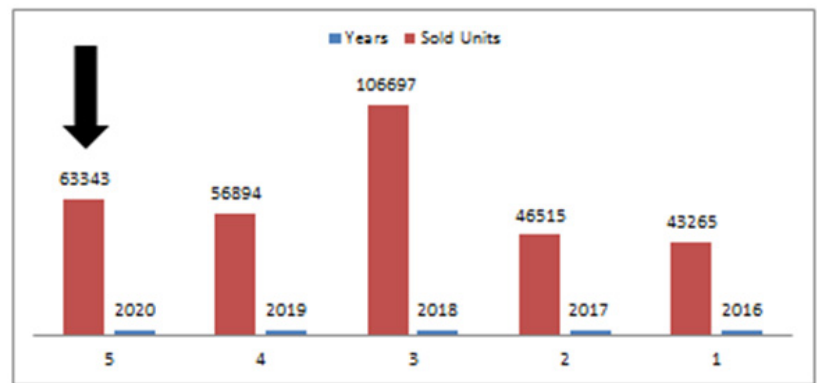

Figure 4: Shows results of the Forecasting for the year 2020 using the four-period moving average method

Using the simple exponential smoothing method, as follows:

Table 6: Shows the results of the Forecasting for the year 2020 using simple exponential Smoothing method (Assuming $\alpha=0.20$ and forecast for the year $2019=71338$ ) (Electrical scales)

\begin{tabular}{|c|c|c|}
\hline Forecasting the quantity sold OF (Electrical scales) For the year 2020 & quantity sold & years \\
\hline $\mathrm{F}_{\mathrm{t}}=\mathrm{F}_{\mathrm{t}-1}+\alpha\left(\mathrm{A}_{\mathrm{t}-1}-\mathrm{F}_{\mathrm{t}-1}\right)$ & 43265 & 2016 \\
\hline $\mathrm{F}_{2020}=71338+0.20(56894-71338)=68449$ & 46515 & 2017 \\
\hline & 106697 & 2018 \\
\hline & 56894 & 2019 \\
\hline $\mathrm{F}_{2020}=68449$ & --------- & 2020 \\
\hline & & \\
\hline
\end{tabular}




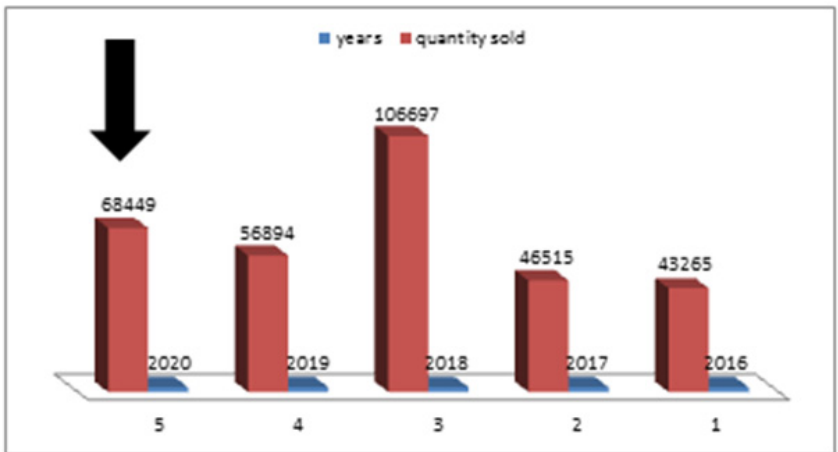

Figure 5: Shows results of the Forecasting for the year 2020 Using the simple exponential smoothing method

\subsubsection{Using Trend line Method as follows}

Table 7: Shows the prediction result for the year 2020 using (Trend line Method)

\begin{tabular}{|c|c|c|c|c|c|}
\hline (6) & (5) & (4) & (3) & (2) & (1) \\
\hline $\mathrm{X}^{2}$ & $\mathrm{XY}$ & Y Sold Units & $\mathrm{X}$ & YEAR NO. & years \\
\hline 25 & -212910 & 42582 & -5 & 1 & 2010 \\
\hline 16 & -414088 & 103522 & -4 & 2 & 2011 \\
\hline 9 & -315714 & 105238 & -3 & 3 & 2012 \\
\hline 4 & -443596 & 221798 & -2 & 4 & 2013 \\
\hline 1 & -137450 & 137450 & -1 & 5 & 2014 \\
\hline 1 & 88872 & 88872 & 1 & 6 & 2015 \\
\hline 4 & 86530 & 43265 & 2 & 7 & 2016 \\
\hline 9 & 139545 & 46515 & 3 & 8 & 2017 \\
\hline 16 & 426788 & 106697 & 4 & 9 & 2018 \\
\hline 25 & 284470 & 56894 & 5 & 10 & 2019 \\
\hline$\sum X^{2}=110$ & $\sum X Y=-497553$ & $\sum Y=952833$ & $\sum \mathrm{X}=\mathrm{ZERO}$ & 11 & 2020 \\
\hline
\end{tabular}

$\mathrm{Y}=\mathrm{a}+\mathrm{b} \mathrm{X}=95283.3+(-123.53 \times 6)=94542.12 \approx 94543$ (Electrical scales) ;

$\mathrm{a}=\sum \mathrm{Y} / \mathrm{n}=952833 / 10=95283.3$;

$\mathrm{b}=\sum \mathrm{XY} / \sum \mathrm{X}_{2}=-497553 / 110=-4523.2$

So: Forecasting the quantity sold OF (Distribution transformers) For the year $2020=3247.82 \approx 3248$ (Electrical scales).

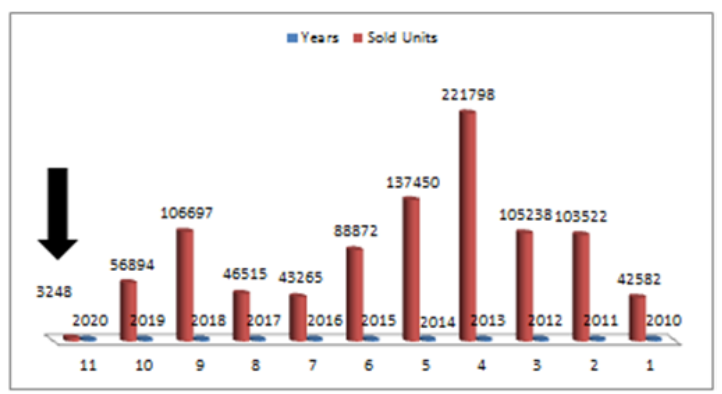

Figure 6: Shows results of the Forecasting for the year 2020 Using the Trend Line Method 
Table 8: Represent Summary of Forecasting for the year 2020 using the four-period moving average method for both products (Electrical scales) \& (Distribution Transformers

\begin{tabular}{|c|c|c|c|c|c|c|c|}
\hline \multicolumn{4}{|c|}{ (Electrical scales) } & \multicolumn{4}{|c|}{ (Distribution Transformers) } \\
\hline \multirow{11}{*}{$\begin{array}{l}\text { Forecasting for the year } 2020 \\
\text { using the four-period moving } \\
\text { average method }\end{array}$} & $\begin{array}{c}\text { production } \\
\text { quantity }\end{array}$ & years & Seq. & \multirow{11}{*}{$\begin{array}{l}\text { Forecasting for the year } 2020 \\
\text { using the four-period moving } \\
\text { average method }\end{array}$} & $\begin{array}{c}\text { production } \\
\text { quantity }\end{array}$ & years & Seq. \\
\hline & 42582 & 2010 & 1 & & 2978 & 2010 & 1 \\
\hline & 103522 & 2011 & 2 & & 5185 & 2011 & 2 \\
\hline & 105238 & 2012 & 3 & & 5392 & 2012 & 3 \\
\hline & 221798 & 2013 & 4 & & 6258 & 2013 & 4 \\
\hline & 137450 & 2014 & 5 & & 3404 & 2014 & 5 \\
\hline & 88872 & 2015 & 6 & & 4928 & 2015 & 6 \\
\hline & 43265 & 2016 & 7 & & 622 & 2016 & 7 \\
\hline & 46515 & 2017 & 8 & & 1549 & 2017 & 8 \\
\hline & 106697 & 2018 & 9 & & 4346 & 2018 & 9 \\
\hline & 56894 & 2019 & 10 & & 5231 & 2019 & 10 \\
\hline 63343 & & 2020 & 11 & 2935 & & 2020 & 11 \\
\hline & & & & & & & \\
\hline
\end{tabular}

Table 9: Represent Summary of Forecasting for the year 2020 using the simple exponential smoothing method for both products (Electrical scales) \& (Distribution Transformers).

\begin{tabular}{|c|c|c|c|c|c|c|c|}
\hline \multicolumn{4}{|c|}{ (Electrical scales) } & \multicolumn{4}{|c|}{ (Distribution Transformers) } \\
\hline \multirow{11}{*}{$\begin{array}{l}\text { Forecasting for the year } 2020 \\
\text { using the simple exponential } \\
\text { smoothing method . }\end{array}$} & $\begin{array}{c}\text { production } \\
\text { quantity }\end{array}$ & years & Seq. & \multirow{11}{*}{$\begin{array}{l}\text { Forecasting for the year } 2020 \\
\text { using the simple exponential } \\
\text { smoothing method }\end{array}$} & $\begin{array}{c}\text { production } \\
\text { quantity }\end{array}$ & years & Seq. \\
\hline & 42582 & 2010 & 1 & & 2978 & 2010 & 1 \\
\hline & 103522 & 2011 & 2 & & 5185 & 2011 & 2 \\
\hline & 105238 & 2012 & 3 & & 5392 & 2012 & 3 \\
\hline & 221798 & 2013 & 4 & & 6258 & 2013 & 4 \\
\hline & 137450 & 2014 & 5 & & 3404 & 2014 & 5 \\
\hline & 88872 & 2015 & 6 & & 4928 & 2015 & 6 \\
\hline & 43265 & 2016 & 7 & & 622 & 2016 & 7 \\
\hline & 46515 & 2017 & 8 & & 1549 & 2017 & 8 \\
\hline & 106697 & 2018 & 9 & & 4346 & 2018 & 9 \\
\hline & 56894 & 2019 & 10 & & 5231 & 2019 & 10 \\
\hline 68449 & & 2020 & 11 & 2935 & & 2020 & 11 \\
\hline
\end{tabular}

Table 10: Represent Summary of Forecasting for the year 2020 using the Trend Line Method for both products (Electrical scales) \& (Distribution Transformers).

\begin{tabular}{|c|c|c|c|c|c|c|c|}
\hline \multicolumn{4}{|c|}{ (Electrical scales) } & \multicolumn{4}{|c|}{ (Distribution Transformers) } \\
\hline \multirow{11}{*}{$\begin{array}{l}\text { Forecasting for the year } 2020 \\
\text { using the Trend line Method .. }\end{array}$} & $\begin{array}{l}\text { production } \\
\text { quantity }\end{array}$ & years & Seq. & \multirow{11}{*}{$\begin{array}{l}\text { Forecasting for the year } 2020 \\
\text { using the Trend line Method .. }\end{array}$} & $\begin{array}{l}\text { production } \\
\text { quantity }\end{array}$ & years & Seq. \\
\hline & 42582 & 2010 & 1 & & 2978 & 2010 & 1 \\
\hline & 103522 & 2011 & 2 & & 5185 & 2011 & 2 \\
\hline & 105238 & 2012 & 3 & & 5392 & 2012 & 3 \\
\hline & 221798 & 2013 & 4 & & 6258 & 2013 & 4 \\
\hline & 137450 & 2014 & 5 & & 3404 & 2014 & 5 \\
\hline & 88872 & 2015 & 6 & & 4928 & 2015 & 6 \\
\hline & 43265 & 2016 & 7 & & 622 & 2016 & 7 \\
\hline & 46515 & 2017 & 8 & & 1549 & 2017 & 8 \\
\hline & 106697 & 2018 & 9 & & 4346 & 2018 & 9 \\
\hline & 56894 & 2019 & 10 & & 5231 & 2019 & 10 \\
\hline 3248 & & 2020 & 11 & 63343 & & 2020 & 11 \\
\hline
\end{tabular}




\section{Conclusions}

1. The company is preparing the contracts concluded with it (Sale by credit) as a result of the financial crisis that Iraq is going through that led to a scarcity of financial resources, which caused a financial crisis for the company that hindered many of its investments for these funds, including the inability to pay salaries and purchase the raw materials entering the industry causing this Decline in the morale of workers in the company.

2. Flooding the local markets with alternative products for the company's products, which led to the discontinuation of the production of ceiling fans, steam irons and mug candles, and this caused the resources not to be invested efficiently and caused production costs to rise due to the failure to utilize the available resources with the full available Capacity.

3. The Ministry of Electricity's reluctance to purchase the company's products despite the quality of the company's products.

4. The fluctuation of the company's production of electrical meter products and distribution transformers has led to difficulty in planning and forecasting production for the coming years, losing opportunities and depriving the company of financial resources.

\section{Recommendations}

1. The company should not sell its products in a way (credit sale), but rather sell it by paying in cash so that it can finance its production activities and pay the workers 'salaries to raise their morale.

2. The Iraqi industry in general requires protection from foreign competitive products in order for these companies to be able to produce and market, especially as the products of Iraqi companies are known for their quality and durability.

3. Directing the Ministry of Electricity to buy the company's products, as these products are no less good than the foreign ones.

4. The reason for the fluctuation in production is due to many problems, including intense competition for foreign products and cheap prices for imported products, as well as a lack of government support for the company, With the disappearance of these problems, production stabilizes and it becomes possible to predict future production, which leads to good planning for the actual needs of the company.

\section{References}

Cecil C. Bozarth, Robert B. Handfield, Introduction to operations and supply chain management, 2nd ed., 2008, Upper Saddle River, New Jersey 07458.

Chase, Richard B., Nicholas J. Aquilano, Operations Management for Competitive Advantage,1oth ed, McGrawHill Companies, Inc, Boston, USA, 2004.

Heizer, J., \&, B. Render, Production \& Operation Management, 3rd., Printice-Hall, New Jersey, 1999.

Krajewski, L., and L. Ritzman. Operations Management: Strategy and Analysis, 6th ed. Upper Saddle River, NJ: Prentice Hall, 2002.

Martin Poiger, Improving performance of supply chain processes by reducing variability, Vienna University of Economics and Business, 2010.

Monk,J.G.,Operations Management,3rd ed., McGraw-Hill, New York,1997.

R. Dan Reid, Nada R. Sanders, Operations Management an Integrated Approach, 4th edition, John Wiley \& Sons, Inc.,2011.

Randall G. Chapman, LINKS Supply Chain Management Fundamentals Simulation, Copyright (c) 2000-2013 by Randall G Chapman,2013.

Roberta S. Russell, Bernard W. Taylor III, Operation Management Creating Value Along the Supply Chain, 7 th edition, John Wiley \& sons, Inc., 2011.

S. Kumar, N. Suresh, Operations Management, Copyright (c) 2009, New Age International (P) Ltd., Publishers Published by New Age International (P) Ltd., Publishers.

Slack, N., S. Chambers, C. Harland, A. Harrison, \&, R. Jonston, Operations Management, 2nd ed., Pitman, 2004.

Slack, N., S. Chambers, C. Harland, A. Harrison, \&, R. Jonston, Operations Management,6th ed., Printic - Hall, 2011. 